ISSN: 2581-8341

Volume 05 Issue 03 March 2022

DOI: 10.47191/ijcsrr/V5-i3-03, Impact Factor: 5.825

IJCSRR@ 2022

www.ijesrr.org

\title{
Proposed Customer Relationship Management and Knowledge Management Strategy (Case Pt. Konsultan Baru Terbarukan)
}

\author{
Mifta Zanaria ${ }^{1}$, Asnan Furinto ${ }^{2}$ \\ ${ }^{1}$ School of Business and Management, Institute Technology of Bandung \\ ${ }^{2}$ Binus Business School, Bina Nusantara University
}

\begin{abstract}
Service consultants in the energy sector in Indonesia are still relatively rare. The business in the field of energy and environmental conservation is something new in Indonesia. Through Presidential Regulation No. 65 of 2021 one of SOE company been transferred all state series B to another Electrical SOE Company The priority program of PT KBT as part of PT LTM (Persero) will focus on developing new businesses in terms of energy and environmental conservation, as well as developing new and renewable energy to support the transformation of PT LTM (Persero) as a green and clean company. The two theme frameworks that would be employed for an effective customer experience strategy are the Customer Relationship Management Value Chain (Francis Buttle, 2019) and Customer Relationship Dimensions (Jain, Jain and Upinder, 2002). In order to improve employee competencies, researcher use knowledge management system those are Coding Analysis and Fishbone Diagram Analysis diagram. This study used a qualitative approach with the interview method conducted online through zoom meetings and also face-to-face interviews. The comprehensive CRM process strategy in order to maximize PT. KBT's strength and opportunity as one of the PT.LTM subsidiaries by using Payne and Frow (2006)'s. The five interconnected stages that will be implemented in the Payne and Frow methodology are: the strategy development, value creation process, multichannel integration process, performance integration process, and information management process. Coding Analysis and Fishbone diagram analysis in this study aims to identify KM problems in PT.KBT. based on the identification results, the authors can propose solutions through KM Objectives which consist of people, process, and technology.
\end{abstract}

KEYWORDS: Consultant Energy Company, Customer Relationship Management, Knowledge Management.

\section{INTRODUCTION}

Service consultants in the energy sector in Indonesia are still relatively rare. The business in the field of energy and environmental conservation is something new in Indonesia. PT. Konsultan Baru Terbarukan (PT.KBT) was originally the only state-owned company appointed by the government to control and manage energy use in Indonesia. PT. KBT itself is engaged in new renewable energy, (NRE) energy conservation, and environmental conservation under the guidance of the Director General of EBTKE, and is a stateowned company in the energy sector, with the most recent establishment in 1993. On May 4, 2021, President Joko Widodo through Presidential Regulation No. 65 of 2021 transferred all state series B shares in PT Konsultan Baru Terbarukan (Persero) to PT Lampu Terang Menyala (Persero). The priority program of PT KBT as part of PT LTM (Persero) will focus on developing new businesses in terms of energy and environmental conservation, as well as developing new and renewable energy to support the transformation of PT LTM (Persero) as a green and clean company. In launching PT.KBT into the LTM group, LTM President Director Zulkifli Zaini targeted PT. KBT to become ESCo (Energy Service Company) in Southest Asia and to get revenue of 8 trillion in the next 5 years. To achieve these business goals and targets, PT. KBT has several strategies, those are strategic partnership and collaboration between SOEs and other LTM subsidiaries. With the strategic partnership and collaboration between these companies, the author would like to propose a strategy related to customer relationship management that can be implemented so that it can help PT.KBT to be able to reach and maintain customers so that they are satisfied with the services provided by PT.KBT. To achieve customer satisfaction, the biggest challenge is the adjustment of PT. KBT as a subsidiary, upgrading KBT's knowledge employees to adhere with LTM standards, both in terms of work systems and corporate systems. This is being important because of how PT.KBT applies knowledge management as a system that can help overcome the obstacles faced by the company. Customer Relationship Management $(\mathrm{CRM})$ is one of the important activities in marketing that helps companies create customized and personalized services for their 


\section{International Journal of Current Science Research and Review}

ISSN: 2581-8341

Volume 05 Issue 03 March 2022

DOI: 10.47191/ijcsrr/V5-i3-03, Impact Factor: 5.825

IJCSRR@ 2022

www.ijesrr.org

customers. To fulfil needs of the customer need the company also relies on knowledge as their most valuable assets. Knowledge is an amalgamation of contextual information, the experience of experts and value that can result in innovation (Abubakar et al., 2019).

\section{MAIN OBJECTIVE}

The purpose of this research is to analyze a comprehensive customer relationship management (CRM) strategy for PT.KBT in order to support company collaboration with fellow subsidiaries of holding company and to analyze that knowledge management strategy in order to improve employee knowledge and competencies.

\section{LITERATURE REVIEW}

\subsection{Customer Relationship Management}

Francis Buttle (2019) CRM is a basic business strategy that strives to design and provide greater value propositions to customers in order to build and retain profitable relationships. According to Chen and Popovich (2003), CRM is not a new concept, but it has gained practical significance as a result of current development and developments in information and corporate software technologies. Relationship marketing is at the heart of CRM, and it aims to improve clients' long-term profitability by moving away from productcentric marketing.

\subsection{Knowledge Management}

Knowledge management is a systematic technique to managing knowledge assets (sourcing, capturing, and deploying) for improved work performance.. Davidson and Voss (2002) Knowledge management is defined as a method that enables businesses to absorb the knowledge, expertise, and creativity of their employees in order to improve company performance. People, process, content/IT, and strategy are the best four components of knowledge management. Regardless of the industry, size, or information demands of the organization, leaders, sponsors, and supporters of knowledge sharing are always needed. To manage and measure knowledge flows, a company needs well-defined processes. Knowledge content and IT systems that link the right people to the appropriate stuff at the right time are required by businesses. Finally, the company requires a well-defined and documented plan for utilizing knowledge management to satisfy the most critical and pressing business demands (Harper, 2019)

\section{METHODOLOGY}

The analysis would then be followed up with the use of thematic frameworks to find the best feasible methods for providing a positive customer experience when using PT.KBT's consultant service in order to retain new and existing clients. The two theme frameworks that would be employed for an effective customer experience strategy are the Customer Relationship Management Value Chain (Francis Buttle, 2019) and Customer Relationship Dimensions (Jain, Jain and Upinder, 2002) in order to improve employee competencies, researcher use knowledge management system Fishbone diagram. This study will be carried out by gathering data or information directly from key informants via face-to-face in-depth interviews, which will be supplemented by interviews with openended questions as a data collection technique.

\section{DATA PROCESSING AND ANALYSIS}

\subsection{Customer Relationship Management Value Chain (Francis Buttle, 2019)}

The CRM value chain process' ultimate goal is to ensure that the organization develops long- term, mutually beneficial connections with its strategic customers. This value chain is made up of five core stages and four supporting conditions that all work together to achieve the final goal of increased customer profitability. The five steps in the CRM value chain are :

\subsubsection{Customer Portfolio Analysis}

The first step in the CRM value chain, Customer Portfolio Analysis, recognizes that not all customers are of similar value to the firm. When CPA divides the real or projected client base into categories, distinct value propositions can be addressed to each category. In this case PT.KBT situation the categorization is divided based on the type of customer company where those included in the invest category are state-owned companies and also companies with large energy users. Companies that are included in the nurture category are private companies where it is necessary to maintain the marketing division in the future in order to become potential customers. 


\section{International Journal of Current Science Research and Review}

ISSN: 2581-8341

Volume 05 Issue 03 March 2022

DOI: 10.47191/ijcsrr/V5-i3-03, Impact Factor: 5.825

IJCSRR@ 2022

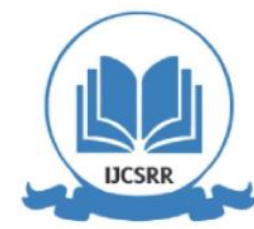

www.ijesrr.org

\subsubsection{Customer Intimacy}

The next stage is to interact with the costumer and expand on the information stored in the database. Companies should collect data on each interaction at each touchpoint in order to better understand and satisfy their customers. PT.KBT conducts customer intimacy by doing research first, capturing the current condition of the customer, and making some assumptions about the condition of the customer's company. After that, hold a meeting with the client to ensure that PT.KBT's assumptions and the customer's needs are in agreement, after matching the scope of work and turning that perception into a Terms of Reference (TOR), then TOR become the initial base for continuous cooperation. To find out whether the customer is satisfied or not, they need to make TOR as their reference which will be adjusted with proposal project, that including the value of the project, the duration of project, and the human resources who will undertake the project.

\subsubsection{Network Development}

Business network consists of all people and entities involved in the value chain, including partners, vendor, expertise, employee, board of directors, etc. CRM requires PT.KBT and PT.LTM as holding company who will make a long-term commitment to CRM strategy implementation by investing in people, processes, and technology. PT. KBT continues to strive to provide services according to customer expectations, for example the Marketing Division seeks to offer products and services owned by PT. KBT. the Operational Division seeks to complete the project, the Human Resource Division plays a role in finding experts/employees. , financial division plays a role in helping to prepare budgets for projects being carried out, the Board of Directors monitors project progress and plays a role in assessing/evaluating project reports before later sent to the client.

\subsubsection{Value Proposition Development}

After gathering as much information as possible about a client and deciding who they want to serve, a corporation may now look for and create sources of value for its chosen clients. PT. KBT's main study at this time is Energy and Environmental Conservation implementation services, also New and Renewable Energy utilization and development,and Decarbonisation, especially in the field of biomass power generation. This is in order to support PT. LTM's commitment to build renewable energy plants (EBT).

\subsubsection{Manage The Customer Lifecycle}

The lifetime of a customer is defined as the path from prospect to customer, when the prospect is happy and content with his relationship and experience with the company and its services, and is ready to become an advocate for the firm. Potential new customers for PT.KBT is the other subsidiaries of PT.LTM and the company that used large amounts of energy (6000 TOE/year). To approach the customers the company used synergies between SOEs and between other PT.LTM subisidiaries. Customer retention strategies will be used is leverage customer feedback surveys, learn from customer complaints, use live webinars to educate product of PT.KBT (especially about conservation energy, decarbonisation, and also the implementation of new and renewable energy), personalize specific communication to each customer. In developing customer value PT.KBT need to understand customers manufacturing process, knowing their product innovation plans (specifically related to new renewable energy), government regulated (related to green economy). The five basic stages of CRM must be supported by certain secondary stages or circumstances in order for the business to reap the full benefits of CRM, there are : Leadership and culture, Data and Information technology, People, and Process.

\subsection{Customer Relationship Dimensions (Jain, Jain and Upinder, 2002)}

CRM provides enormous benefits to the firm in terms of increased sales, market share profitability, customer satisfaction, and reduced customer turnover, service cost, and time (Jain,Jain and Upinder, 2002: 100-101). Based on results the interview with one of customer PT.KBT, can be conclude that PT.KBT already have a quite good intense, responsive, fast respons, and have willingness to learn attitude. From 'undestanding expectation' of PT.KBT, they already finished the project with appropriate in terms of time and quality but it still doesn't meet client beyond expectation. In terms of communication with PT.KBT its good and there are no obstacles, becomes "time consuming" when having a discussion with PT. KBT because it must to explained first the fundamental foundations owned by PT.LTM. in terms of Quality perceptions PT. KBT employees are quite responsive, and have a great desire to ask questions and learn. From reliability PT.KBT still needs to improve their experience, and knowledge. The customers has no problems related to the services provided by PT.KBT. According to the scope of work, PT. KBT has a match between the initial and final work scope., In order to keep the customer as a client, it is also required to communicate with PT.LTM as the customer holding company. The customer also advises PT.KBT to keep their responsive and communicative attitude, but also to improve their own competency. 


\section{International Journal of Current Science Research and Review}

ISSN: 2581-8341

Volume 05 Issue 03 March 2022

DOI: 10.47191/ijcsrr/V5-i3-03, Impact Factor: 5.825

IJCSRR@ 2022

WwW.ijcsrr.org

\subsection{Fishbone Diagram}

Fishbone diagrams (also known as Ishikawa diagrams or cause-and-effect diagrams) are a graphical tool for displaying the various causes of a certain event or phenomena (Coccia, 2017). It can be seen that the issue occurred in the PT. KBT and cause by the following reasons : 1) People : In terms of skill and experience new entry employees is still limited, sometimes they are still unsure how to meet customer expectations, especially in terms of technological difficulties should be addressed. Due to the limited number of human resources, it affects the quality of the products produced. There is a lack on innovation from audit energy employees. There are also lack of employees in middle level. Their employee also have a lack awareness of employee to contribute in knowledge sharing session. 2) Process : There are lack of communication between each division. There are no human capital development training for new employee that makes employee felt difficult to adapt with the culture of organization. There is no routine meeting to meet each division, meeting will be happened depends on the project condition. There is no routine activity related to sharing knowledge. There is a program knowledge sharing session but turns out their program was not running well. Basically, knowledge transfer occurs by word of mouth when there is discussion related about the project. The employee felt that they don't have of work life balanced due to because they often do overtime in the weekdays and sometimes still working on weekend. 3) Technology : The technology used to store all data needs related to knowledge, literature journal references, and also databases related to projects that have been carried out is still limited to using dropbox

\section{FISHBONE DIAGRAM}

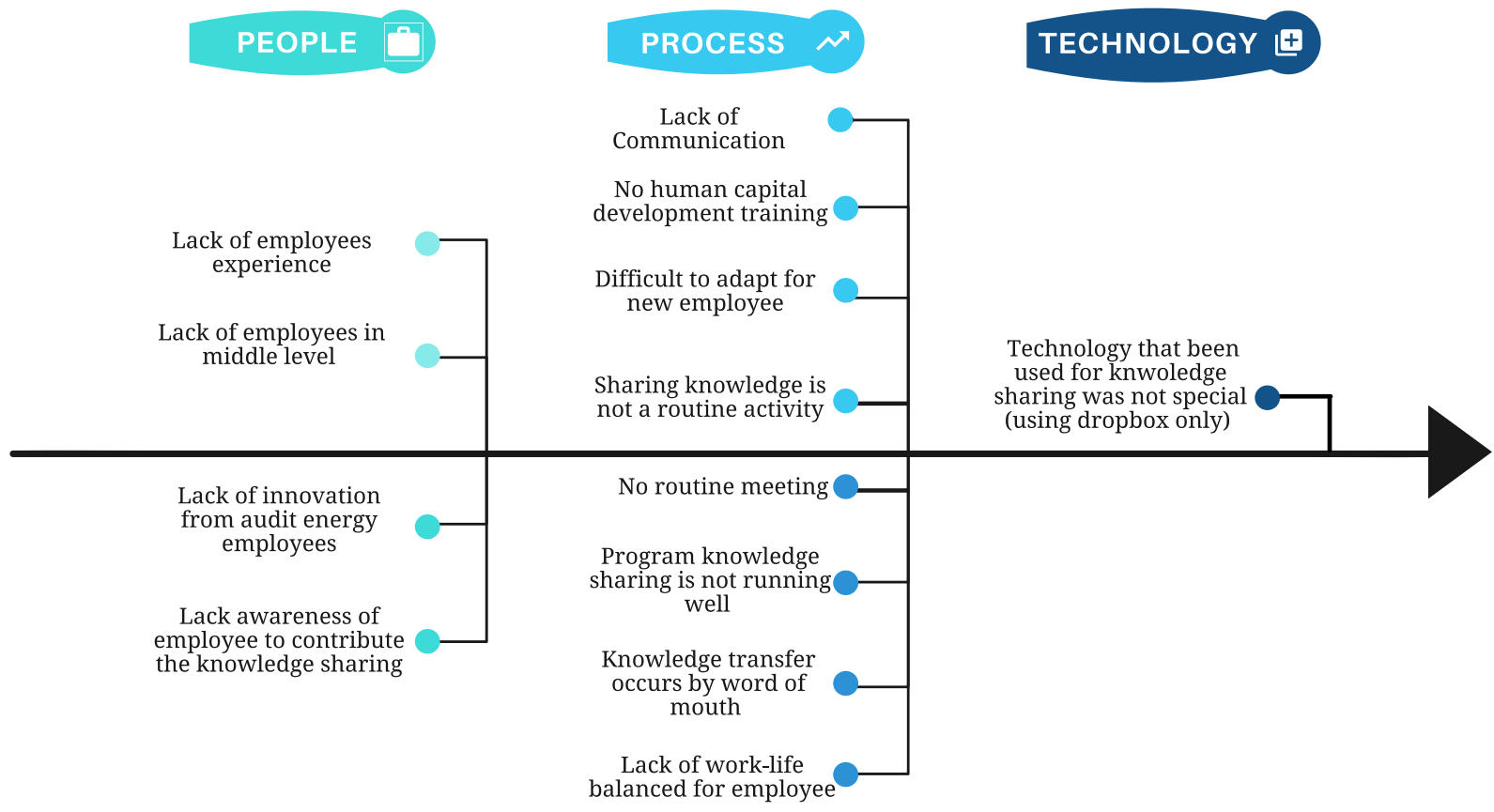

Figure 1. Fishbone Diagram Analysis

\section{FINDINGS AND ARGUMENTS}

\subsection{Payne and Frow Framework (2006)}

The Payne and Frow conceptual framework is a CRM strategy approach focused on increasing shareholder value by developing appropriate elationships with key customers and customer categories that are appropriate. CRM combines the power of relationship marketing an information technology to help customers and other key stakeholders develop profitable, long-term relationships. This needs a cross-functional integration of processes, people, operations, and marketing skills, all of which must be backed by data, technology, and applications.. The five interconnected stages that will be implemented in the Payne and Frow methodology are: the strategy development, value creation process, multichannel integration process. 


\section{International Journal of Current Science Research and Review}

ISSN: 2581-8341

Volume 05 Issue 03 March 2022

DOI: 10.47191/ijcsrr/V5-i3-03, Impact Factor: 5.825

IJCSRR@ 2022

www.ijesrr.org

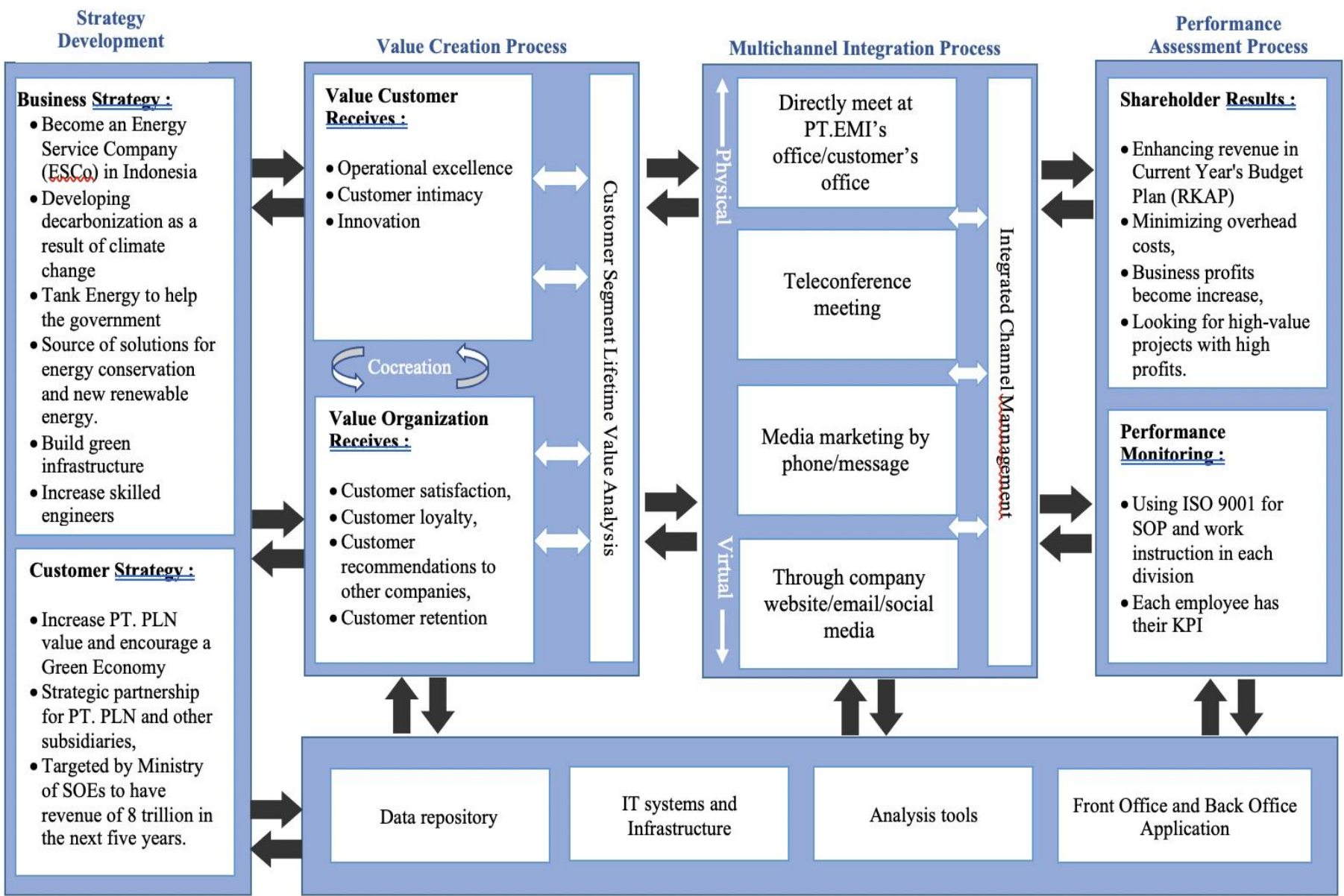

Information Management Process

Figure 2. CRM Strategy Framework for PT.KBT Implemetation

\subsection{People, Process, Technology Framework}

PT.KBT currently lacks a dedicated to knowledge management. However, there are acts within the company that pertain to personnel management, documenting and transferring knowledge to other division units. The knowledge management framework within the organization is organized into three components: people, process, and technology. 


\section{International Journal of Current Science Research and Review}

ISSN: 2581-8341

Volume 05 Issue 03 March 2022

DOI: 10.47191/ijesrr/V5-i3-03, Impact Factor: 5.825

IJCSRR@ 2022

Table 1. Knowledge Management Objectives of PT.KBT

\begin{tabular}{|c|c|c|c|c|c|}
\hline & \multirow[b]{2}{*}{ Root Cause } & \multirow{2}{*}{ KM Objectives } & \multicolumn{3}{|c|}{ KM Strategies } \\
\hline & & & People & Process & Technology \\
\hline \multirow{4}{*}{ People } & $\begin{array}{l}\text { Lack of employees } \\
\text { experience (in entry level) }\end{array}$ & $\begin{array}{l}\text { Employees receive training } \\
\text { based on their position. }\end{array}$ & $\begin{array}{l}\text { Head of } \\
\text { Division }\end{array}$ & $\begin{array}{l}\text { Coaching mentoring, } \\
\text { Virtual Meetings, } \\
\text { Knowledge Sharing } \\
\text { Forum }\end{array}$ & $\begin{array}{l}\text { Workshop, Video } \\
\text { Conference }\end{array}$ \\
\hline & $\begin{array}{l}\text { Lack of employees in } \\
\text { middle level }\end{array}$ & $\begin{array}{l}\text { Increased employee at the } \\
\text { middle management level }\end{array}$ & $\begin{array}{l}\text { Head of } \\
\text { Division }\end{array}$ & $\begin{array}{l}\text { Recruitment middle } \\
\text { level }\end{array}$ & Video Conference \\
\hline & $\begin{array}{l}\text { Lack of innovation from } \\
\text { energy auditor employees }\end{array}$ & $\begin{array}{l}\text { Take implementation action } \\
\text { on the results of the energy } \\
\text { audit }\end{array}$ & $\begin{array}{l}\text { Head of } \\
\text { Division }\end{array}$ & $\begin{array}{l}\text { Lesson learn paper, } \\
\text { Project report }\end{array}$ & $\begin{array}{l}\text { Workshop, Video } \\
\text { Conference, } \\
\text { Repository, } \\
\text { Database }\end{array}$ \\
\hline & $\begin{array}{l}\text { Lack awareness of } \\
\text { employee to contribute the } \\
\text { knowledge sharing }\end{array}$ & $\begin{array}{l}\text { Add knowledge sharing as a } \\
\text { performance indicator for } \\
\text { employees. }\end{array}$ & $\begin{array}{l}\text { Head of } \\
\text { Division }\end{array}$ & $\begin{array}{l}\text { Knowledge Café, } \\
\text { Knowledge Sharing } \\
\text { forum, } \\
\end{array}$ & $\begin{array}{l}\text { Workshop, Video } \\
\text { Conference }\end{array}$ \\
\hline \multirow{8}{*}{ Process } & Lack of communication & $\begin{array}{l}\text { Communicating important } \\
\text { information quickly }\end{array}$ & $\begin{array}{l}\text { Head of } \\
\text { Division }\end{array}$ & $\begin{array}{l}\text { Knowledge Café, } \\
\text { Virtual Meetings }\end{array}$ & $\begin{array}{l}\text { Workshop, Video } \\
\text { Conference, } \\
\text { Groupware }\end{array}$ \\
\hline & $\begin{array}{l}\text { No human capital } \\
\text { development training }\end{array}$ & $\begin{array}{l}\text { New employees are given } \\
\text { company introduction }\end{array}$ & $\begin{array}{l}\text { Head of } \\
\text { Finance and } \\
\text { Adminitration } \\
\text { Division }\end{array}$ & $\begin{array}{l}\text { Lesson learn paper, } \\
\text { Training and } \\
\text { Development, }\end{array}$ & $\begin{array}{l}\text { Workshop, Intranet, } \\
\text { Video Conference }\end{array}$ \\
\hline & $\begin{array}{l}\text { Difficult to adapt for new } \\
\text { employee }\end{array}$ & $\begin{array}{l}\text { New employee orientation } \\
\text { program at the company }\end{array}$ & $\begin{array}{l}\text { Head of } \\
\text { Finance and } \\
\text { Adminitration } \\
\text { Division }\end{array}$ & $\begin{array}{l}\text { Knowledge café, } \\
\text { knowledge sharing } \\
\text { forum }\end{array}$ & $\begin{array}{l}\text { Repository, } \\
\text { database }\end{array}$ \\
\hline & No routine meeting & $\begin{array}{l}\text { Each division is required to } \\
\text { hold a weekly meeting } \\
\text { preferably the day before the } \\
\text { management meeting }\end{array}$ & $\begin{array}{l}\text { Head of } \\
\text { Division }\end{array}$ & $\begin{array}{l}\text { Briefing session, } \\
\text { Virtual meetings }\end{array}$ & $\begin{array}{l}\text { Video Conference, } \\
\text { Workshop }\end{array}$ \\
\hline & $\begin{array}{l}\text { Sharing knowledge is not a } \\
\text { routine activity }\end{array}$ & $\begin{array}{l}\text { The weekly regular meeting } \\
\text { agenda includes time for } \\
\text { knowledge sharing. }\end{array}$ & $\begin{array}{l}\text { Head of } \\
\text { Division }\end{array}$ & $\begin{array}{l}\text { Knowledge café, } \\
\text { knowledge sharing } \\
\text { forum, Virtual } \\
\text { meetings }\end{array}$ & $\begin{array}{l}\text { Workshop, Video } \\
\text { Conference, }\end{array}$ \\
\hline & $\begin{array}{l}\text { Program knowledge } \\
\text { sharing is not running well }\end{array}$ & $\begin{array}{l}\text { Reactivation of the } \\
\text { knowledge sharing program }\end{array}$ & $\begin{array}{l}\text { Head of } \\
\text { Finance and } \\
\text { Adminitration } \\
\text { Division }\end{array}$ & $\begin{array}{l}\text { Knowledge café, } \\
\text { knowledge sharing } \\
\text { forum, Virtual } \\
\text { meetings }\end{array}$ & $\begin{array}{l}\text { Workshop, Video } \\
\text { Conference, }\end{array}$ \\
\hline & $\begin{array}{l}\text { Knowledge transfer occurs } \\
\text { by word of mouth }\end{array}$ & $\begin{array}{l}\text { Make a paper/resume project } \\
\text { from the results of the work } \\
\text { to become knowledge } \\
\text { management material }\end{array}$ & $\begin{array}{c}\text { Project } \\
\text { Manager }\end{array}$ & $\begin{array}{l}\text { Lesson learns papers, } \\
\text { Project report, } \\
\text { Knowledge Cafe }\end{array}$ & $\begin{array}{c}\text { Repository, } \\
\text { Database, Intranet }\end{array}$ \\
\hline & $\begin{array}{l}\text { Lack of work life balanced } \\
\text { for employee }\end{array}$ & $\begin{array}{l}\text { Set working hours and } \\
\text { divided time by priority }\end{array}$ & $\begin{array}{l}\text { Head of } \\
\text { Division }\end{array}$ & $\begin{array}{l}\text { Determine work } \\
\text { prioritities }\end{array}$ & Groupware \\
\hline Technology & $\begin{array}{l}\text { Technology that been used } \\
\text { for knowledge sharing was } \\
\text { not special (dropbox only) }\end{array}$ & $\begin{array}{l}\text { Provide a centralized } \\
\text { database server that is highly } \\
\text { secure and accessible to all } \\
\text { employees, and that can be } \\
\text { updated immediately } \\
\text { whenever new data is } \\
\text { received. }\end{array}$ & $\begin{array}{l}\text { Head of } \\
\text { Division }\end{array}$ & $\begin{array}{l}\text { Data Management } \\
\text { System, }\end{array}$ & $\begin{array}{l}\text { Database, Server, } \\
\text { Repository, } \\
\text { Intranet, } \\
\text { Groupware, Portals }\end{array}$ \\
\hline
\end{tabular}

\section{CONCLUSION}

The current situation which opens up many new opportunities for PT. KBT to work together, it is very necessary for employees who can understand both in terms of the products to be offered and also the service consulting project that will be carried out. Based on Francis Buttle's (2009) CRM Value Chain method, PT. KBT prioritizing SOE customers as well as customers with the highest energy users in Indonesia. PT. KBT has engaged customers in terms of customer intimacy by attempting to match client demands with the company's capabilities. PT.KBT has also separated the responsibilities of each division in terms of working on customer projects. In order to synergize with customers, PT. KBT has also selected which items will be the primary focus.

Researcher used Jain, Jain and Upinder (2002)'s framework to Measuring the effectiveness of CRM programme. PT. KBT has fulfilled these 10 aspects, but there are still some things that need to be improved, especially regarding the knowledge of employees. The 


\section{International Journal of Current Science Research and Review}

ISSN: 2581-8341

Volume 05 Issue 03 March 2022

DOI: 10.47191/ijcsrr/V5-i3-03, Impact Factor: 5.825

IJCSRR@ 2022

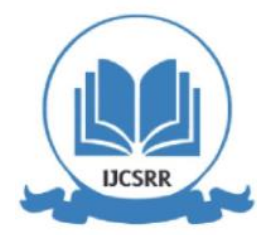

www.ijcsrr.org

comprehensive CRM process strategy in order to maximize PT. KBT's strength and opportunity as one of the PT.LTM subsidiaries by using Payne and Frow (2006)'s. The five interconnected stages that will be implemented in the Payne and Frow methodology are: the strategy development process, value creation process, value creation process, multichannel integration process, performance integration process, and information management process. Fishbone diagram analysis in this study aims to identify KM problems in PT.KBT. based on the identification results, the authors can propose solutions through KM Objectives which consist of people, process, and technology.

\section{REFERENCES}

1. Abubakar, A.M., Elrehail, H., Alatailat, M. A \& Elci, A. 2019. Knowledge management, decision-making style and organisational performance. Journal of Innovation \& Knowledge 4 (2), 104-114.

2. Harper, Mercy. (2019). What are the Best Four Components of Knowledge Management?. APQC, October 19. Available from https://www.apqc.org/blog/what-are-best-four-components-knowledge-management [Accessed 0n 17 December 2021]

3. Buttle, F., \& Maklan, S. (2019). Customer Relationship Management: Concepts and Technologies (4th ed.). Routledge.

4. Chain, I. (2017). Knowledge Management Hybrid Strategy with People, Technology and Process Pillars. College of Professional and Continuing Education. HK : The Hong Kong Politechnic University.

5. Coccia, Mario, The Fishbone Diagram to Identify, Systematize and Analyze the Sources of General Purpose Technologies (January 11, 2018). Journal of Social and Administrative Sciences, vol. 4, n. 4, pp. 291-303.

6. Jain, R., Jain, S. and Upinder, D. (2002), 'Measuring Customer Relationship Management'. Journal of Service Research, vol.2, no.2, October, pp. 97-109

7. Payne, A., \& Frow, P. (2005). A strategic framework for customer relationship management. Journal of marketing, 167-176.

Cite this Article: Mifta Zanaria, Asnan Furinto (2022). Proposed Customer Relationship Management and Knowledge Management Strategy (Case Pt. Konsultan Baru Terbarukan). International Journal of Current Science Research and Review, 5(3), 625-631 